\title{
Effect of pH on the Formation of Acylated Octreotides by Poly(lactide-co-glycolide)
}

\author{
Dong Hee $\mathrm{Na}^{\dagger}$
}

\author{
College of Pharmacy, Kyungsung University, 314-79 Daeyeon-dong, Nam-ku, Busan 608-736, South Korea
}

(Received July 20, 2010 • Revised July 28, $2010 \cdot$ Accepted July 29, 2010)

\begin{abstract}
The formation of acylated peptide impurities in poly(lactide-co-glycolide) (PLGA) formulations is one of the major challenges to the development of successful sustained-release product. Octreotide, synthetic analogue of somatostatin, has been identified to be acylated in PLGA microsphere formulations. The purpose of this study was to investigate the $\mathrm{pH}$ effect on the formation of acylated octreotides by PLGA. In the incubation with PLGA in 0.1 M phosphate buffer at $\mathrm{pH} 7.4$, approximately $98 \%$ of octreotide adsorbed to PLGA through 14 days and $66.3 \%$ of acylated octreotides were produced after 42 days, whereas the interaction of octreotide with PLGA was significantly inhibited in the incubation at $\mathrm{pH}$ 4 , in which the acylated octreotides were observed to be $9.2 \%$ after 42 days. In the interaction study at $\mathrm{pH} 4.1-7.4$, the production of acylated octreotides was demonstrated to be dependent on environmental $\mathrm{pH}$. Below $\mathrm{pH}$ 5.0, the acylation of octreotide was significantly inhibited. This study indicates that the $\mathrm{pH}$ is the major factor for the formation of acylated octreotide in PLGA formulations.
\end{abstract}

Key words - Octreotide, Stability, Peptide acylation, Poly(lactide-co-glycolide)

Biodegradable poly(D,L-lactide-co-glycolide) (PLGA), copolymer of lactic and glycolic acids, has been extensively used for the sustained-release drug delivery and tissue engineering because of its highly biocompatible and biodegradable characteristics (Gombotz and Pettit, 1995; Anderson and Shive, 1997). Injectable biodegradable microspheres and implants prepared using PLGA provide a distinct advantage over daily injections by controlling the release of the encapsulated peptides or proteins over the course of weeks to months (Sinha and Trehan, 2005). Sustained depot formulations of luteinizing hormone-releasing hormone and somatostatin analogues have been commercialized, such as the Lupron Depot $^{\circledR}$ (leuprolide acetate), Zoladex ${ }^{\circledR}$ implant (goserelin acetate), and Sandostatin LAR $^{\circledR}$ (octreotide acetate), and several additional products are under clinical investigation (Wischke and Schwendeman, 2008).

Although biodegradable PLGA has been successfully used for the long-term controlled drug release, the instability of peptides and proteins in the PLGA matrix during manufacture, storage and after administration remains one of the major challenges to successful product development (Bilati et al., 2005). Recently, the formation of peptide impurities inside or outside PLGA matrix as a result of peptide acylation with lactic and glycolic acid units was found in various peptides such as

†Corresponding Author:

Tel : +82-51-663-4881, E-mail : dhna2@ks.ac.kr

DOI : 10.4333/KPS.2010.40.4.251 salmon calcitonin, atrial natriuretic peptide, human parathyroid hormone, growth hormone-releasing peptide- 6 (Lucke et al., 2002; Na et al., 2003; Na and DeLuca, 2005; Murty et al., 2005a; Murty et al., 2005b; Houchin et al., 2006; Na et al., 2007; Ryu and Na, 2009). The formation of acylated peptide impurities in PLGA formulations is regarded as one of obstacles to be overcome for the successful drug delivery, because it may be the cause of the incomplete drug release, and can lead to changes in the biological properties of peptides, such as the loss of biological activity or a change in immunogenicity (Na et al., 2007).

Octreotide, which is a synthetic octapeptide analogue of the naturally occurring hormone somatostatin $\left(\mathrm{H}_{2} \mathrm{~N}-\mathrm{DPhe}-\mathrm{Cys}-\right.$ Phe-DTrp-Lys-Thr-Cys-Thr-ol) and exerts pharmacologic actions similar to the endogenous somatostatin (Chen et al., 1993), has been commercially formulated in PLGA microsphere formulations (Sandostatin LAR depot, Novartis, Basel, Switzerland) as a monthly dosage form for the treatment of acromegaly and certain endocrine tumors. In several previous studies with octreotide, the peptide acylation has been shown to occur in PLGA microsphere formulations (Murty et al., 2005a; Murty et al., 2005b; Na and DeLuca, 2005; Ryu and Na, 2009). The primary amines of octreotide at $\mathrm{N}$-terminus and lysine side chain are identified to be the major targets for peptide acylation by PLGA (Na and DeLuca, 2005). The acylation of octreotide with PLGA was proposed to involve an ionic interaction between a protonated amine (mainly $\varepsilon$-amine of lysine residue) and carboxylate of PLGA end-group, followed by a nucleo- 


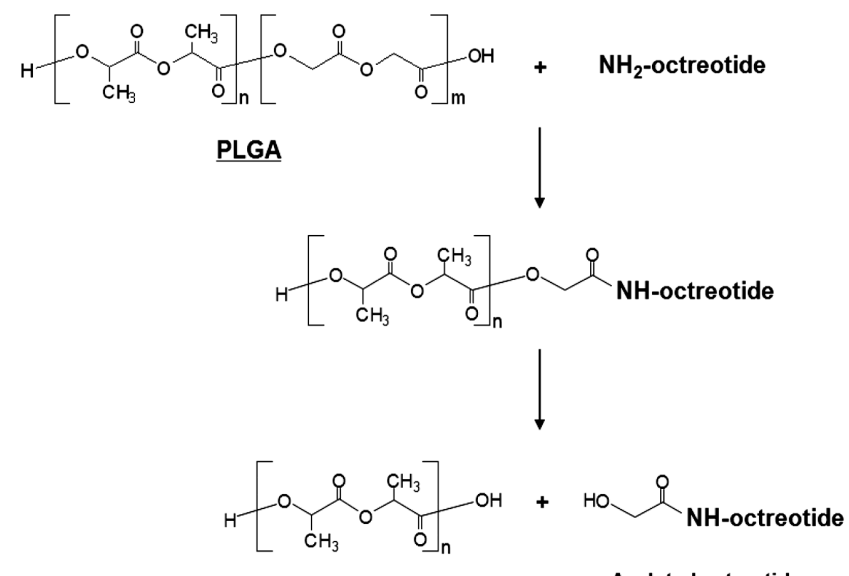

Figure 1. The formation of acylated octreotides by reaction with PLGA and the subsequent hydrolysis of polymer.

philic attack of another primary amine (mainly $\mathrm{N}$-terminal amine) on the lactate or glycolate carbonyl carbon and subsequent hydrolysis of PLGA (Figure 1).

The purpose of this study was to investigate the effect of $\mathrm{pH}$ on the formation of acylated octreotides by interacting with PLGA. As indicated in the previous study (Na and DeLuca, 2005), the primary amines of N-terminus and lysine residue of octreotide play an important role in the peptide acylation by PLGA and their roles may be dependent on environmental $\mathrm{pH}$. This study monitors the formation of acylated octreotides at different $\mathrm{pH}$ and elucidates the importance of $\mathrm{pH}$ control for inhibiting peptide acylation.

\section{Materials and Methods}

\section{Materials}

Octreotide acetate (molecular weight 1019.26) was obtained from Bachem (Torrance, CA, USA). Hydrophilic 50:50 PLGA polymer (molar ratio of D,L-lactide: glycolide $=50: 50$, viscosity: 0.16-0.24 dL/g, product name: RESORMER ${ }^{\circledR}$ RG502H) was supplied by Boehringer Ingelheim (Ingelheim, Germany). DL-lactic acid, glycolic acid, and $\alpha$-cyano-4-hydroxycinnamic acid ( $\alpha$-CHCA) were purchased from Sigma (St. Louis, MO, USA). Acetonitrile (HPLC grade) and trifluoroacetic acid (TFA) were obtained from J.T. Baker (Philipsburg, NJ, USA) and Acros organic (Pittsburgh, PA, USA), respectively. All other chemicals were of analytical grade and were used as obtained commercially.

\section{Interaction Study of Octreotide with PLGA}

The formation of acylated octreotides by PLGA was investigated by adding $100 \mathrm{mg}$ of RG502H PLGA polymer to
$10 \mathrm{~mL}$ of octreotide (peptide concentration of $200 \mu \mathrm{g} / \mathrm{mL}$ ) in $0.1 \mathrm{M}$ acetate buffer ( $\mathrm{pH} 4.0$ ) or $0.1 \mathrm{M}$ phosphate buffer $(\mathrm{pH}$ $7.4)$ at $37^{\circ} \mathrm{C}(\mathrm{n}=3$ per sample). Samples were collected at 1,3 , $7,14,21,28,35$, and 42 days. The supernatants after centrifuge were analyzed by reversed phase-HPLC in triplicate per sample.

\section{Effect of pH on Octreotide Acylation by PLGA}

Effect of $\mathrm{pH}$ on the formation of acylated octreotides by PLGA was investigated at the range of $\mathrm{pH} 4.1-7.4$ with $0.1 \mathrm{M}$ phosphate buffers containing lactic acid or glycolic acid. 10 $\mathrm{mg}$ of RG502H PLGA polymer was added to $1 \mathrm{~mL}$ of octreotide (peptide concentration of $200 \mu \mathrm{g} / \mathrm{mL}$ ) in $0.1 \mathrm{M}$ phosphate buffers ( $\mathrm{pH} 7.4$ ) containing $0.2 \%(\mathrm{pH} 6.9), 0.4 \%(\mathrm{pH}$ $6.4), 0.6 \%(\mathrm{pH} 5.8)$, or $1.0 \%(\mathrm{pH} 4.1)$ of lactic acid or $0.6 \%$ of glycolic acid $(\mathrm{pH} 5.0)$ at $55^{\circ} \mathrm{C}(\mathrm{n}=3$ per sample). Samples were collected at 1,3 , and 10 days. The supernatants after centrifuge were analyzed by reversed phase-HPLC in triplicate per sample.

\section{HPLC Analysis}

HPLC analysis was performed with a Dionex HPLC system (Dionex Co., Sunnyvale, CA, USA) consisted of a quaternary gradient pump with an on-line vacuum degasser (Model P680A), an automated sample injector (Model ASI-100), thermostatted column compartment (Model TCC-100) and 4-channel multi UV-vis detector (Model 170U). Separations of octreotide and its acylated products were carried out on a Prosphere C-18 column $(4.6 \times 250 \mathrm{~mm}, 5 \mu \mathrm{m}$, Alltech, Deerfield, IL, USA) with a Prosphere C-18 guard column $(4.6 \times 7.5 \mathrm{~mm}$, $5 \mu \mathrm{m}$, Alltech, Deerfield, IL, USA). A gradient elution was performed with mobile phase A $(0.1 \%$ TFA in water) and mobile phase B $(0.1 \%$ TFA in acetonitrile). Linear gradient elution was performed from 80:20 to 65:35 (mobile phase $\mathrm{A}: \mathrm{B})$ for $20 \mathrm{~min}$ at a flow rate of $1.0 \mathrm{~mL} / \mathrm{min}$. Total run time was $30 \mathrm{~min}$ and sample injection volume was $40 \mu \mathrm{L}$. UV absorbances were monitored at $215 \mathrm{~nm}$.

\section{MALDI-TOF Mass Spectrometry}

Matrix-assisted laser desorption/ionization time-of-flight mass spectrometry (MALDI-TOF MS) analysis was performed on a Kratos Kompact SEQ time-of-flight mass spectrometer (Manchester, UK) as reported previously ( $\mathrm{Na}$ and DeLuca, 2005). The $\alpha$-CHCA in $50 \%$ of acetonitrile in water with $0.1 \%$ TFA was used as a matrix. Data for 2 ns pulses of the $337 \mathrm{~nm}$ nitrogen laser were averaged for each spectrum in a linear mode, and positive ion TOF detection was performed using an accelerating voltage of $20 \mathrm{kV}$. 


\section{Results and Discussion}

The formation of acylated octreotides by interaction with PLGA was monitored in $0.1 \mathrm{M}$ acetate buffer ( $\mathrm{pH} 4.0$ ) and 0.1 $\mathrm{M}$ phosphate buffer ( $\mathrm{pH} \mathrm{7.4)}$ ) at $37^{\circ} \mathrm{C}$ for 6 weeks. In a previous study (Na and DeLuca, 2005), the interaction between octreotide and PLGA was observed with initial adsorption of octreotide to PLGA followed by chemical reaction and the release of native and acylated octreotides (Figure 1). Figure 2(A) shows the interaction profile of octreotide with hydrophilic RG502H PLGA in $0.1 \mathrm{M}$ sodium phosphate buffer at $\mathrm{pH}$ 7.4. From day 1 through day 14, approximately $2.2 \%$ of octreotide remained in the supernatant and then the amount increased to $33.2 \%$ by day 42 . The acylated octreotide was observed from day $14(5.2 \%)$ and the amount increased to $66.3 \%$ by day 42 . At day 42 , the sum of amounts of the native and acylated octreotides reached $99.5 \%$. In the MALDI-TOF MS analysis of samples at 42 days, several acylated octreotides with the additional mass of glycolic acid (GA, $58 \mathrm{Da}$ ) and/or

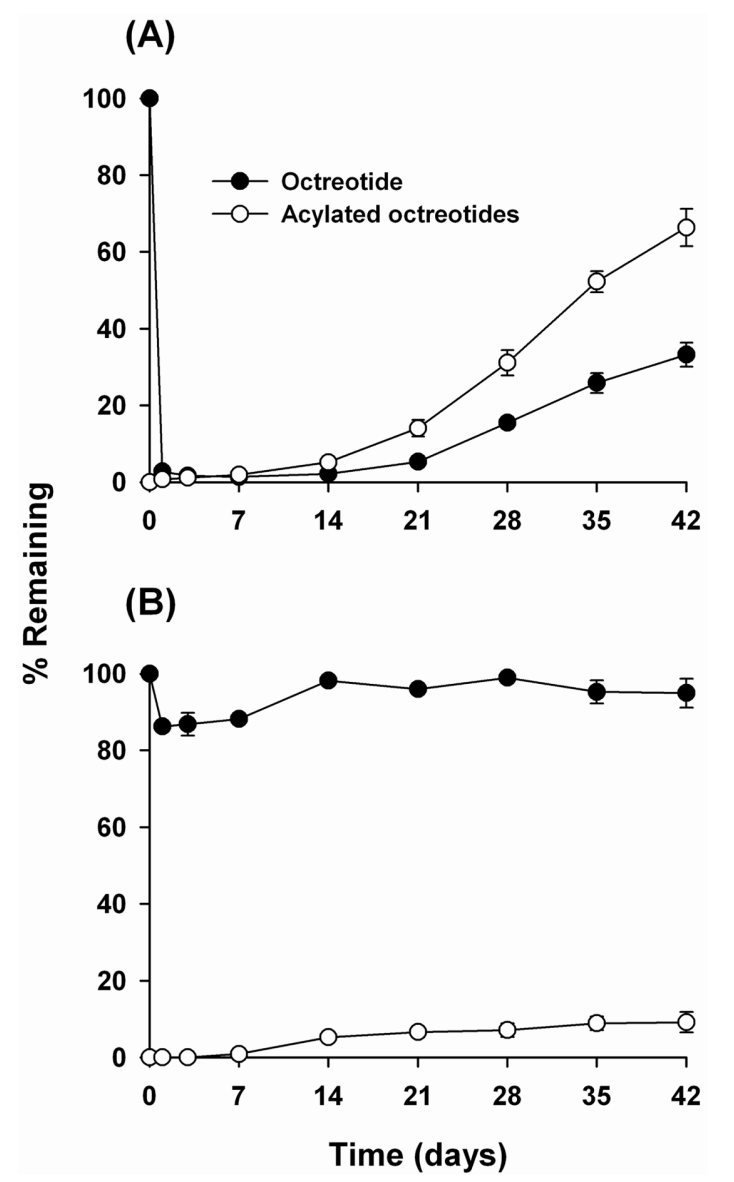

Figure 2. The production of acylated octreotides after incubating octreotide with PLGA in $0.1 \mathrm{M}$ phosphate buffer (pH 7.4) (A) and $0.1 \mathrm{M}$ acetate buffer ( $\mathrm{pH} 4.0$ ) (B) at $37^{\circ} \mathrm{C}$ for 42 days. lactic acid (LA, $72 \mathrm{Da}$ ) units were observed as follows: octreotide-1GA, $m / z$ 1077; octreotide-1LA, $m / z$ 1091; octreotide$\mathrm{Na}$ (sodium)-1GA, $m / z$ 1100; octreotide-1Na-LA, $m / z$ 1114; octreotide-2GA, $\mathrm{m} / \mathrm{z}$ 1135; octreotide-1GA-1LA, $\mathrm{m} / z$ 1149; octreotide-Na-2GA, $m / z$ 1158; octreotide-Na-1GA-1LA, $m / z$ 1172; octreotide-Na-3GA, $m / z$ 1216; octreotide-Na-2GA-1LA, $\mathrm{m} / z 1230$.

The interaction profile of octreotide with hydrophilic RG502H PLGA in $0.1 \mathrm{M}$ sodium acetate buffer at $\mathrm{pH} 4$ was shown in Figure 2(B). At $\mathrm{pH} 4$, the interaction of octreotide with PLGA was significantly inhibited. At day 1, approximately $86.2 \%$ of octreotide remained in the supernatant and the acylation products of octreotide were observed to be 5.3$9.2 \%$ from day 14 to 42 . This result indicates that the initial adsorption of octreotide to PLGA and the subsequent reaction of octreotide with PLGA are dependent on the environmental $\mathrm{pH}$.

To further investigate the $\mathrm{pH}$ effect on the formation of acy-

(A)

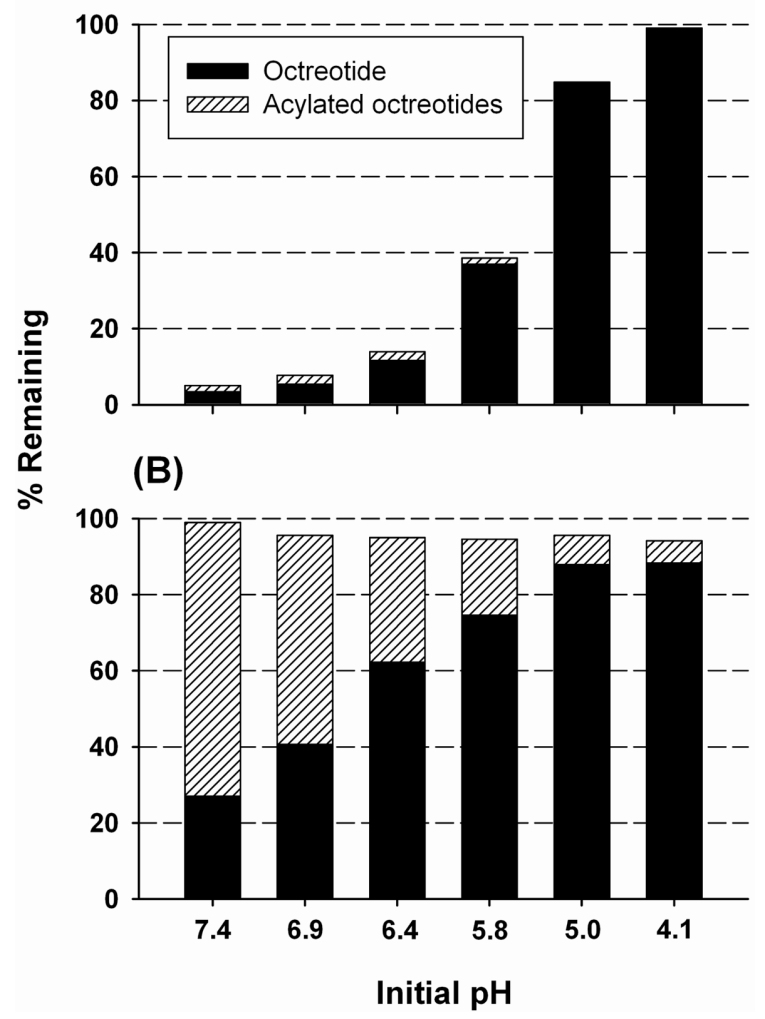

Figure 3. Effect of $\mathrm{pH}$ on the formation of acylated octreotides by PLGA after 1 day (A) and 10 days (B) of incubation in different $\mathrm{pH}$ buffers at $55^{\circ} \mathrm{C}$. Initial $\mathrm{pH}$ 7.4: $0.1 \mathrm{M}$ phosphate buffer, $\mathrm{pH}$ 6.9: 0.1 $\mathrm{M}$ phosphate buffer containing $0.2 \%$ lactic acid, $\mathrm{pH}$ 6.4: $0.1 \mathrm{M}$ phosphate buffer containing 0.4\% lactic acid, $\mathrm{pH}$ 5.8: $0.1 \mathrm{M}$ phosphate buffer containing $0.6 \%$ lactic acid, $\mathrm{pH} 5.0$ : $0.1 \mathrm{M}$ phosphate buffer containing $0.6 \%$ glycolic acid, $\mathrm{pH}$ 4.1: $0.1 \mathrm{M}$ phosphate buffer containing $1.0 \%$ lactic acid. 
lated octreotides by PLGA, octreotide was incubated with hydrophilic RG502H PLGA polymer in various buffers ranged from $\mathrm{pH} 4.1$ to 7.4 at $55^{\circ} \mathrm{C}$. The solutions ranged from $\mathrm{pH} 6.9$ to 4.1 were prepared by the addition of $0.2-1.0 \%(\mathrm{v} / \mathrm{v})$ lactic acid or glycolic acid. After incubation for 10 days at $55^{\circ} \mathrm{C}$, the $\mathrm{pH}$ values of every solution were significantly lowered to $\mathrm{pH}$ 3.5-3.2. Figure 3(A) shows initial adsorption of octreotide to PLGA polymer at day 1 . The adsorption was significant in the solutions at the initial $\mathrm{pH} 7.4-5.8$, whereas the solutions at the initial $\mathrm{pH} 5.0$ and 4.1 showed substantially lower adsorption. The initial adsorption was closely related to the formation of acylated octreotides. As shown in Figure 3(B), the acylated octreotides were substantially formed in the solutions at the initial $\mathrm{pH}$ ranged from 7.4 to 5.8 , whereas the octreotide acylation was inhibited in the solutions at the initial $\mathrm{pH}$ below 5.0. With initial $\mathrm{pH} 5.8$, approximately $20 \%$ of octreotide was acylated, whereas $7.7 \%$ of octreotide were acylated at initial $\mathrm{pH}$ 5.0. This result indicates that the acylation of octreotide occurs at initial drug release stage in the microspheres prior to the formation of acidic microclimate within the PLGA matrix owing to polymer degradation.

\section{Conclusion}

The $\mathrm{pH}$ is major factor for the formation of acylated octreotides in PLGA formulations. At neutral $\mathrm{pH}$, several acylated octreotides were produced via initial adsorption to PLGA followed by acylation reaction and hydrolysis of polymer. The formation of acylated octreotides by PLGA could be significantly inhibited at acidic $\mathrm{pH}$. Therefore, the control of initial $\mathrm{pH}$ inside PLGA matrix may be one of strategies for preventing from the acylation of octreotide in PLGA formulations.

\section{Acknowledgements}

This research was supported by Kyungsung University Research Grants in 2010.

\section{References}

Anderson, J.M., Shive, M.S., 1997. Biodegradation and biocompatibility of PLA and PLGA microspheres. Adv. Drug Deliv.
Rev 28, 5-24.

Bilati, U., Allemann, E., Doelker, E., 2005. Strategic approaches for overcoming peptide and protein instability within biodegradable nano- and microparticles. Eur. J. Pharm. Biopharm 59, 375-388.

Chen, F., O'Dorisio, M.S., Hermann, G., Hayes, J., Malarkey, W.B., O'Dorisio, T.M., 1993. Mechanisms of action of long-acting analogs of somatostatin, Regul. Pept 44, 285-295.

Gombotz, W.R., Pettit, D.K., 1995. Biodegradable polymers for protein and peptide drug delivery. Bioconjug. Chem 6, 332351.

Houchin, M.L., Heppert, K., Topp, E.M., 2006. Deamidation, acylation and proteolysis of a model peptide in PLGA films. J. Control. Release 112, 111-119.

Lucke, A., Kiermaier, J., Gopferich, A., 2002. Peptide acylation by poly(alpha-hydroxy esters). Pharm. Res 19, 175-181.

Murty, S.B., Thanoo, B.C., Wei, Q., DeLuca, P.P., 2005a. Impurity formation studies with peptide-loaded polymeric microspheres: Part I. In vivo evaluation. Int. J. Pharm 297, 50-61.

Murty, S.B., Na, D.H., Thanoo, B.C., DeLuca, P.P., 2005b. Impurity formation studies with peptide-loaded polymeric microspheres: Part II. In vitro evaluation. Int. J. Pharm 297, 62-72.

Na, D.H., Youn, Y.S., Lee, S.D., Son, M.W., Kim, W.B., DeLuca, P.P., Lee, K.C., 2003. Monitoring of peptide acylation inside degrading PLGA microspheres by capillary electrophoresis and MALDI-TOF mass spectrometry. J. Control. Release 92, 291-299.

Na, D.H., DeLuca, P.P., 2005. PEGylation of octreotide: I. Separation of positional isomers and stability against acylation by poly(D,L-lactide-co-glycolide). Pharm. Res 22, 736-742.

Na, D.H., Lee, J.E., Jang, S.W., Lee, K.C., 2007. Formation of acylated growth hormone-releasing peptide- 6 by poly(lactide-coglycolide) and its biological activity. AAPS PharmSciTech 8 , article 43.

Ryu, K.W., Na, D.H., 2009. Stability of octreotide acetate in aqueous solutions and PLGA films. J. Kor. Pharm. Sci 39, 353-357.

Sinha, V.R., Trehan, A., 2005. Biodegradable microspheres for parenteral delivery. Crit. Rev. Ther. Drug Carrier Syst 22, 535602.

Van de Weert, M., Hennink, W.E., Jiskoot, W., 2000. Protein instability in poly(lactic-co-glycolic acid) microparticles, Pharm. Res 17, 1159-1167.

Wischke, C., Schwendeman, S.P., 2008. Principles of encapsulating hydrophobic drugs in PLA/PLGA microparticles. Int. J. Pharm 364, 298-327. 